Systemic lupus eryth ematosus (SLE) is a disorder with a wide range of immunological abnormalities. The results of the studies undertaken in the last decade indicated that SLE pathogenesis was mainly connected with the breakdown of the activation control of $B$ and $T$ cells, generating humoral or cell-mediated responses against several self-antigens of affected cells. The last studies demonstrate that the role of $\gamma \delta$ $T$ lymphocytes in autoimmune diseases can be especially important. Flow cytometry techniques were used to investigate the number and percentage of TCR $\gamma \delta \mathrm{T}$ cells and their most frequent subtypes in peripheral blood of 32 patients with SLE and 16 healthy volunteers. We also correlated TCR $\gamma \delta$ cells number with the level of $\mathrm{T} \mathrm{CD3}^{+}, \mathrm{T} \mathrm{CD4}^{+}, \mathrm{T} \mathrm{CD8}^{+}$, and NK (CD16) cells (cytometric measurements) and SLE activity (on the basis of clinical investigations). Our studies were preliminary attem pts to evaluate the role of that minor T cell subpopulation in SLE. Absolute numbers of cells expressing $\gamma \delta$ TCR in most SLE blood specimens were significantly lower than in the control group $(P<0.006)$. However, since the level of to tal $T$ cell population was also decreased in the case of SLE, the mean values of the percentage $\gamma \delta$ T cells of pan $T$ lymphocytes were almost the same in both analysed populations $(7.1 \%$ vs $6.3 \%$, respectively). In con trast to $V \delta 2^{+}$and $V \gamma 9^{+}$subtypes of pan $\gamma \delta \mathrm{T}$ cells, $\mathrm{V} \delta 3^{+} \mathrm{T}$ cells number was higher in SLE patients $(20 \times$ 10 cells $/ \mu \mathrm{l})$ than in healthy control group $(2 \times 2$ cells $/ \mu \mathrm{l})(P=0.001)$. However, we found no differences between the numbers of pan $\gamma \delta \mathrm{T}$ lymphocytes and studied their subtypes in the patients with active and in active disease. These cell subpopulations were doubled in the treated patients with immunosuppressive agents in comparison with untreated ones; however, data were not statistically significant. Our study indicated that $V \delta 3^{+}$subtype of $\gamma \delta \mathrm{T}$ cells seems to be involved in SLE pathogenesis; however, we accept the idea that the autoimmunity does not develop from a single abnormality, but rather from a number of different events.

Key words: SLE, Lymphocytes, $\gamma \delta$ T cells, NK cells, Disease activity

\section{Circulating TCR $\gamma \delta$ cells in the patients with systemic lupus erythematosus}

\author{
Ewa Robak', Jerzy Z. Błoński², Jacek Bartkowiak ${ }^{3}$, \\ Hanna Niewiadomska ${ }^{4}$, Anna Sysa-Jẹdrzejowska ${ }^{1}$ \\ and Tadeusz Robak ${ }^{2, C A}$
}

${ }^{1}$ Department of Dermatology and Venerology;

${ }^{2}$ Department of Hematology; ${ }^{3}$ Department of Molecular Biology and ${ }^{4}$ Department of Oncology,

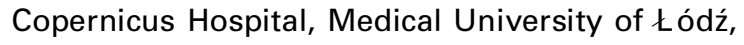
Poland

\author{
${ }^{\mathrm{CA}}$ Corresponding Author \\ Department of Hematology, Medical University of Lódź, \\ Copernicus Hospital, ul. Pabianicka 62, 93-513 Lódź, \\ Poland \\ Tel./fax: + (48 42) 6846890 \\ Email: robaktad@psk2.am.lodz.pl
}

\section{Introduction}

Systemic lupus erythematosus (SLE) is a disorder with a wide range of immunological abnormalities. The disease is characterized by $B$ cell activation and formation of autoantibodies against nuclear, cytoplasmic and cell surface antigens. ${ }^{1,2}$ However, increasing evidence indicates a critical role of $\mathrm{T}$ cells, particular $\mathrm{CD}^{+}$cells in inducing $\mathrm{B}$ cell hyperactivity. ${ }^{3}$ On the other hand, insufficient suppressor cell activity may be responsible for autoantibody overproduction. Defective concanavalin A-induced suppressor cell function ${ }^{4,5}$ and suppressor/cytotoxic responses to Epstein-Barr virus (EBV) ${ }^{6}$ have been demonstrated in
SLE patients. Most human mature T cells express $\alpha \beta$ T-cell receptors on the membrane (TCR $\alpha \beta$ ) in association with the signal transduction of $\mathrm{CD} 3$ complex. These TCR $\alpha \beta$ T cells are the central lymphocytes in the immune system. They provide specific pathogen recognition and long-term memory all within the context of distinguishing foreign from self antigens. ${ }^{7}$

Subpopulation of T-cell, which expresses TCR $\gamma \delta$ receptors $\left(\gamma \delta\right.$ T cells) was identified 15 years ago a,9 $^{8,9}$ but its significance in immune response and pathogenesis of different diseases is still poorly understood. TCR $\gamma \delta$ receptors represent a disulphide-linked heterodimer composed of rearranged $\gamma$ and $\delta$ chains 
homologous to the TCR $\alpha \beta$ and Ig heavy and light chains, which contribute to specificity of T cells and B cells. ${ }^{10}$ Human $\gamma \delta \mathrm{T}$ cells range from $1 \%$ to $15 \%$ of peripheral blood lymphocytes and show a predilection for the red pulp of the spleen and the gastrointestinal tract. ${ }^{11,12} \gamma \delta \mathrm{T}$ cells play a role in host epithelial surface control and early stage engagement in immune response against viruses, bacteria and parasites before the recruitment of $\alpha \beta$ T cells. ${ }^{7}$ They are able to react with antigens both in a major histocompatibility complex (MHC) -restricted and MHC-unrestricted fashion. ${ }^{13}$

The pathologic relevance of $\gamma \delta$ cells in human autoimmune diseases is suggeste $\mathrm{d}$ by their reactivity to highly conserved stress proteins and by the accumulation of $\gamma \delta$ T cells in affected organs. ${ }^{14-17}$ The possible role of $\gamma \delta \mathrm{T}$ cells in autoimmune disease is also raised by their ability to recognise self antigens. Increased percentages of TCR $\gamma \delta$ cells have been found in the synovial fluids and synovia of patients with active rheumatoid arthritis. ${ }^{18,19}$ A number of studies suggest that $\gamma \delta \mathrm{T}$ cells play a role in the pathogenesis of systemic sclerosis. ${ }^{20,21}$ Increased numbers of $\gamma \delta$ T cells have been found in perivascular areas of the skin and bronchoalveolar lavage samples, especially in patients with recently diagnosed disease. Clonal expansion of TCR $\gamma \delta$ T cells has been also reported in the periphery of patients with systemic lupus erythematosus (SLE). ${ }^{22}$ Furthermore, Volc-Platzer et al. described preferential expansion of $V \gamma 2 / V \delta 2$ subset in lesions in chronic cutaneous lupus erythe matosus. ${ }^{23}$

In the present study we measured the number of to tal circulating TCR $\gamma \delta$ cells and their subpopulations in 32 SLE patients and in 16 healthy volunteers using monoclonal antibodies against pan- $\gamma \delta, V \delta 2, V \delta 3, V \gamma 9$ chain regions and flow cytometry techniques. We also correlated the number of $\gamma \delta \mathrm{T}$ cells with $\mathrm{T} \mathrm{CD}^{+}, \mathrm{T}$ $\mathrm{CD}^{+}, \mathrm{T} \mathrm{CD}^{+}$and NK (CD16) cells and SLE activity.

\section{Patients and methods}

\section{Patients}

A total of 32 unselected patients with SLE, 30 women and two men all fulfilling the 1982 revised criteria defined by the American Rheumatism Association $(\text { ARA })^{24}$ were included in our study. Their mean age was 43.7 years (range 22-65 years). The mean duration of the disease was 84.2 months (range 3 months to 28 years). Ten patients had never been treated with steroids or any other immunosuppressive agents, 22 patients had been treated with prednisone and two of them with azatioprine for some time during the course of their disease, but 12 of them had not been treated for at least 4 weeks before the $\gamma \delta \mathrm{T}$ cell population analysis.

We included both patients with active and inactive disease into the study. Disease activity was scored
Table 1. Clinical and laboratory characteristics of the patient with SLE (symptoms according to Liang et al. ${ }^{25}$

\begin{tabular}{lrr}
\hline Symptom & $\begin{array}{c}\text { Number of } \\
\text { patients }\end{array}$ & \\
& & \\
\hline Total & 32 & 100 \\
Active & 23 & 71.8 \\
Inactive & 9 & 28.2 \\
Fever & 7 & 21.9 \\
Arthritis & 18 & 56.2 \\
Skin symptoms & 16 & 50.0 \\
Reticuloendothelial system involvement & 15 & 46.9 \\
Pulmonary symptoms & 4 & 12.5 \\
Cardiovascular symptoms & 16 & 50.0 \\
Neurologic symptoms & 19 & 59.4 \\
Renal disorder (creatinine $>1.3 \mathrm{mg} / \mathrm{dL})$ & 2 & 6.2 \\
Antinuclear antibodies & 32 & 100.0 \\
Anaemia (Hb<12 g/dL) & 11 & 34.4 \\
Leukopenia (WBC $<.5\left(10^{9} / \mathrm{L}\right)$ & 9 & 28.1 \\
Thrombocytopenia (PLT<150(10 9 /L) & 6 & 18.7 \\
Raised ESR $(>25 \mathrm{~mm} / \mathrm{h})$ & 29 & 90.6 \\
Treatment with steroids during the study & 22 & 68.7 \\
& & \\
\hline
\end{tabular}

during a visit to the outpatient clinic according to the method described by Liang et al. ${ }^{25}$ Each patient was assessed on two separate occasions, 2-4 weeks apart. The system of Systemic Lupus Activity Measure (SLAM) includes 24 clinical manifestations and eight laboratory parameters. The maximum score in this system amounts to 84 points. In our group of patients, the points ranged from 6 to 26 . We considered the score of $0-10$ points indicative of inactive disease, and a score of over 10 points indicative of active disease. This decision was based on our previous observations ${ }^{26,27}$ that patients with score 10 had no clinical symptoms of active disease such as photosensitivity, fever, polyarthritis, serositis, an elevated erythrocyte sedimentation rate or a high antinuclear antibody level (ANA). A similar distinction between active and inactive disease was also performed by other authors. ${ }^{28}$ Our group of patients included 9 patients with inactive and 23 patients with active disease. The clinical and laboratory features of SLE patients are presented in Table 1. The control group of 16 healthy volunteers was also studied. They were 12 women and 4 men, aged from 37 to 56 years (mean 48 years). Each underwent a through physical evaluation by one of the authors (ER).

\section{Laboratory tests}

On the day of blood sampling for T cells immunophenotyping, the following laboratory parameters were analysed: complete blood cell count $(\mathrm{CBC})$, erythrocyte sedimentation rate, blood urea nitrogen and creatinine levels, fibrinogen level, partial thromboplastin time (PTT), liver function tests (GOT, GPT, bilirubin), immunoglobulins ( $\operatorname{IgG}, \operatorname{Ig} A, \operatorname{Ig} M$ ) and complement $\left(C_{3}, C_{4}\right)$, urine and creatinine levels, and anti-DNA antibodies. Chest X-rays and ECG were also evaluated. 


\section{Immunophenotype analysis}

Venous blood samples were collected at the time of clinical assessment into pyrogen-free tubes, containing anticoagulant (EDTA at a final concentration of $25 \mathrm{mM}$ ). General lymphocyte immunophenotyping and TCR diversity analysis were performed by standard two-colour immunofluorescence measurement. The details of the procedure are described elsewhere. ${ }^{29}$ Briefly a combination of phycoerythrin (PE)conjugated and fluorescein isothiocyanate (FITC)conjugated monoclonal (MoAbs) was used. In polystyrene tubes $100 \mu \mathrm{l}$ of whole blood were directly stained with $10 \mu \mathrm{l}$ appropriate MoAbs in the dark at room temperature. IgG1 isotype control antibody conjugates were included in order to establish the background fluorescence. After incubation for $30 \mathrm{~min}$, the samples were placed to Q-prep (Coulter) for lysis of erythrocytes and fixation of nuclear cells. At least 10,000 cells were then analysed on a Coulter Epics-XL flow cytometer (Coulter, Hialeah, FL, USA). Gate Check was used to gate lymphocyte population defined by FS/SS and anti CD14 and CD45RO MoAbs. Analysis was performed using XLv2 software.

\section{Monoclonal antibodies}

The direct staining of cells by monoclonal antibodies (MoAbs) was performed. We were able to use only commercially prepared MoAbs conjugated with proper fluorochrome-PE-conjugated UCHT1 $\left(\mathrm{CD}^{+}\right.$, pan T), IMMU510 (all $\gamma \delta \mathrm{T}$ cells), FITC-conjugated 13B8.2 $\left(\mathrm{CD}^{+}{ }^{+} \mathrm{T}\right.$ cells), B9.11 (CD8 ${ }^{+} \mathrm{T}$ cells), 3G8
$\left(\mathrm{CD} 16^{+}\right.$, mainly $\mathrm{NK}$ and at some percentage $\gamma \delta \mathrm{T}$ cells), IMMU510 (all $\gamma \delta \mathrm{T}$ cells), IMMU389 (V82, specific domain of $\delta$ chain TCR), P11.5B (V83, specific domain of $\delta$ chain TCR), IMMU360 ( $V \gamma 9$, specific domain of $\gamma$ chain TCR), were all supplied by Immunotech (A Coulter Company, USA). The anti-V $\delta 1$ (Immunotech) was available as the plain proteins and was not applied for staining in whole blood samples together with other MoAbs. It was used for indirect phenotyping of isolated lymphocytes. In these experiments the goat/anti-mouse IgG (FITC and PE conjugated $\mathrm{F}\left(2 \mathrm{ab} \mathrm{b}^{\prime}\right)_{2}$ fragments) was used for counterstaining.

\section{Statistical analysis}

The analysis of the results indicated that normal distribution was observed for almost all studied variables. We presented our calculations as a mean \pm SD. The universal Mann-Whitney U test was used for determination of differences in quantity of studied cell populations. For phenotypic feature correlation between studied T and NK cell populations, measured simultaneously in the same patient, we used the Spearman rank test. Statistically characteristic changes were considered at $P<0.05$.

\section{Results}

The $\gamma \delta$ TCR expression on peripheral blood T lymphocytes from 32 SLE patients and 16 healthy donors has been determined using standard doublecolour immunofluorescence measurement. Their clin-

Table 2. Characteristics of peripheral blood parameters in SLE patients and healthy donors (mean values \pm SD and range in parentheses)

\begin{tabular}{|c|c|c|c|}
\hline Characteristic & $\begin{array}{c}\text { SLE patients } \\
N=32\end{array}$ & $\begin{array}{c}\text { Controls } \\
\qquad N=16\end{array}$ & $P$ value \\
\hline $\mathrm{Hb} \mathrm{g} / \mathrm{dL}$ & $\begin{array}{l}12.4 \pm 1.5 \\
(9.7-17.3)\end{array}$ & $\begin{array}{r}14.2 \pm 1.5 \\
(12.4-16.0)\end{array}$ & NS \\
\hline Platelets $\left(10^{6} / \mathrm{L}\right)$ & $\begin{array}{l}194.0 \pm 68.9 \\
(30.0-369.0)\end{array}$ & $\begin{array}{r}258.4 \pm 89.9 \\
(156.5-426.4)\end{array}$ & 0.005 \\
\hline $\mathrm{WBC} / \mu \mathrm{I}$ & $\begin{array}{r}4851.0 \pm 2055.0 \\
(2320.0-10450.0)\end{array}$ & $\begin{array}{r}7148.0 \pm 1635.0 \\
(5540.0-10100.0)\end{array}$ & 0.008 \\
\hline Pan T $\left(\mathrm{CD}^{+}\right)$cells $/ \mu \mathrm{l}$ & $\begin{array}{r}630 \pm 330 \\
(170-1360)\end{array}$ & $\begin{array}{l}1025.0 \pm 256.0 \\
(603.0-1415.0)\end{array}$ & 0.003 \\
\hline $\mathrm{T} \mathrm{CD} 4^{+}$cells $/ \mu \mid$ & $\begin{array}{c}220 \pm 140 \\
(440-570)\end{array}$ & $\begin{array}{c}500 \pm 180 \\
(310-890)\end{array}$ & 0.001 \\
\hline $\mathrm{T} \mathrm{CD}^{+}$cells $/ \mu \mathrm{l}$ & $\begin{array}{l}360 \pm 230 \\
(90-830)\end{array}$ & $\begin{array}{c}450 \pm 140 \\
(200-620)\end{array}$ & NS \\
\hline Ratio $\mathrm{CD}^{+} / \mathrm{CD}^{+}$cells & $\begin{array}{c}0.77 \pm 0.54 \\
(0.25-1.50)\end{array}$ & $\begin{array}{c}1.24 \pm 0.21 \\
(0.56-1.70)\end{array}$ & 0.005 \\
\hline NK cells $/ \mu$ I & $\begin{array}{l}120 \pm 100 \\
(10-770)\end{array}$ & $\begin{array}{l}290 \pm 170 \\
(60-550)\end{array}$ & 0.004 \\
\hline Pan B $\left(C D 19^{+}\right)$cells $/ \mu$ I & $\begin{array}{l}640 \pm 540 \\
(95-3760)\end{array}$ & $\begin{array}{r}530 \pm 220 \\
(300-1020)\end{array}$ & NS \\
\hline
\end{tabular}


Table 3. Analysis of $\gamma \delta$ TCR expression on circulating T cells of SLE patients and healthy donors (mean of cells number/ $\mu \mathrm{I} \pm \mathrm{SD}$ and range in parentheses)

\begin{tabular}{|c|c|c|c|c|c|c|}
\hline \multirow{2}{*}{$\begin{array}{l}\text { Cell } \\
\text { Subpopulation }\end{array}$} & \multicolumn{3}{|c|}{ Number of $\gamma \delta$ cells $/ \mu \mathrm{l}$} & \multicolumn{3}{|c|}{ Percentage $\gamma \delta \mathrm{T}$ cells of pan T cells } \\
\hline & $\begin{array}{c}\text { SLE } \\
\text { Mean } \pm \text { SD } \\
\text { (range) }\end{array}$ & $\begin{array}{c}\text { Control } \\
\text { Mean } \pm \text { SD } \\
(\text { range })\end{array}$ & $P$ value & $\begin{array}{c}\text { SLE } \\
\text { Mean } \pm \text { SD } \\
\text { (range) }\end{array}$ & $\begin{array}{c}\text { Control } \\
\text { Mean } \pm \text { SD } \\
(\text { range })\end{array}$ & $P$ value \\
\hline $\operatorname{Pan} \gamma \delta \mathrm{TCR}^{+}$ & $\begin{array}{l}40 \pm 30 \\
(0-140)\end{array}$ & $\begin{array}{c}67 \pm 39 \\
(19-154)\end{array}$ & 0.006 & $\begin{array}{l}7.1 \pm 6.5 \\
(1.2-26.9)\end{array}$ & $\begin{array}{c}6.3 \pm 3.9 \\
(1.5-13.1)\end{array}$ & 0.7 \\
\hline $\mathrm{V} \delta 2 \mathrm{TCR}^{+}$ & $\begin{array}{l}20 \pm 10 \\
(0-100)\end{array}$ & $\begin{array}{c}50 \pm 41 \\
(3-147)\end{array}$ & 0.003 & $\begin{array}{c}3.6 \pm 4.1 \\
(0.15-19.6)\end{array}$ & $\begin{array}{c}4.5 \pm 3.6 \\
(0.3-12.5)\end{array}$ & 0.03 \\
\hline V83 $\mathrm{TCR}^{+}$ & $\begin{array}{l}20 \pm 10 \\
(0-100)\end{array}$ & $\begin{array}{l}2 \pm 2 \\
(0-7)\end{array}$ & 0.001 & $\begin{array}{l}4.2 \pm 5.7 \\
(0-21.4)\end{array}$ & $\begin{array}{l}0.2 \pm 0.1 \\
(0.1-0.6)\end{array}$ & 0.0003 \\
\hline $\mathrm{V} \gamma 9 \mathrm{TCR}^{+}$ & $\begin{array}{l}20 \pm 20 \\
(0-110)\end{array}$ & $\begin{array}{c}49 \pm 40 \\
(3-131)\end{array}$ & 0.005 & $\begin{array}{l}4.1 \pm 4.6 \\
(0.4-21.2)\end{array}$ & $\begin{array}{c}4.1 \pm 3.0 \\
(0.3-11.1)\end{array}$ & 0.1 \\
\hline
\end{tabular}

ical data are summarised in Table 1 . Detailed characteristics of peripheral blood parameters, both for SLE patients and for the healthy donors, are shown in Table 2. The absolute numbers of WBC, pan $\mathrm{T} \mathrm{CD}^{+}$, $\mathrm{CD}^{+}, \mathrm{CD}^{+}$cells and $\mathrm{NK}$ cells were significantly lower in SLE patients than in the control group. In contrast, the absolute numbers of cytotoxic/suppressor $\left(\mathrm{CD}^{+} \mathrm{CD}^{+}\right)$and pan $\mathrm{B}\left(\mathrm{CD} 19^{+}\right)$cells in both groups were similar.

The mean absolute values and percentages of $\gamma \delta \mathrm{T}$ cells and their subpopulations in peripheral blood of SLE patients and in healthy individuals are presented in Table 3. The mean absolute number of pan $\gamma \delta \mathrm{T}$ cells was lower in SLE patients $(40 \pm 30 / \mu \mathrm{l})$ than in controls $(67 \pm 39 / \mu \mathrm{l}) \quad(\mathrm{p}=0.006)$. However, the percentage of $\gamma \delta \mathrm{T}$ cells of pan T cells was similar in both groups $(7.1 \% \pm 6.5 \%$ and $6.3 \% \pm 3.9 \%$, respectively) $(P=0.7)$. A comparable decrease of circulating V $\delta 2$ and V $\delta 9$ subtypes of pan $\gamma \delta$ T cells in SLE patients $(20 \pm 10 \mathrm{cells} / \mu \mathrm{l}$ and $20 \pm 20 \mathrm{cells} / \mu \mathrm{l}$, respectively $)$ in relation to normal controls $(50 \pm 41 \mathrm{cells} / \mu \mathrm{l}$ and $49 \pm$ 40 cells $/ \mu 1$, respectively) $(P=0.003$ and 0.005$)$ was observed. On the other hand, the absolute number of $\mathrm{V} \delta 3^{+}$subtypes of $\gamma \delta$ cells was significantly higher in

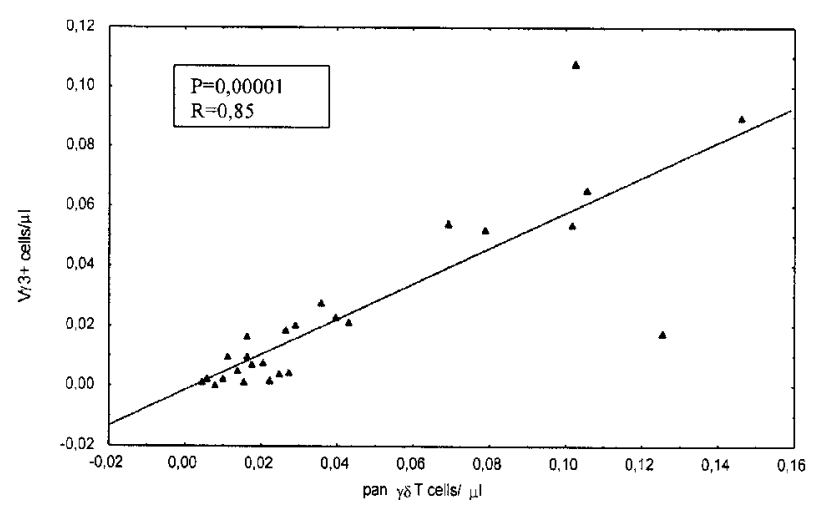

FIG. 1. Correlation between pan $\gamma \delta^{+} T$ cells number and the number of ${\mathrm{V} \delta 3^{+}}^{+}$cells in SLE patients. peripheral blood of SLE patients $(20 \pm 10$ cells $/ \mu 1)$ than in control donors $(2 \pm 21$ cells $/ \mu 1)(P=0.001)$. A similar difference was noted in the percentage of this subpopulation in both groups $(4.2 \% \pm 5.7 \%$ vs $2 \% \pm$ $0.1 \%$, respectively; $P=0.0003$ ). Although the above calculated values for $V \delta 3^{+}$cell subtypes were different for particular SLE patients (see ranges and SD in Table 3), we found in patients blood specimens a distinct positive correlation between peripheral blood absolute numbers of $\gamma \delta \mathrm{T}$ cells and the number of $\mathrm{V} \delta 3^{+}$ cells $(R=0.85, P=0.00001)$ (Fig. 1$)$. This very high correlation coefficient for $\mathrm{V} \delta 3^{+}$lymphocytes provided additional strong evidence, that this $\gamma \delta \mathrm{T}$ subtype could play some role in SLE activity.

It should be noticed that $\gamma \delta$ T cell levels practically did not fluctuate if the analytical tests for particular patients were repeated two or three times. However, the follow up of $\gamma \delta \mathrm{T}$ lymphocytes changes during disease development were not done.

Data presented in Table 3 showed that threequarters of pan $\gamma \delta \mathrm{T}$ cells in the blood of healthy individuals expressed V $\delta 2$ and V $\gamma 9$ TCR chains. Although the above result was obtained in separate staining measurements, we can univocally conclude that the subfraction $V \delta 2 / V \gamma 9$ is the most frequent in normal blood, as stated in several works. ${ }^{7}$ In SLE patients the proportion of $V \delta 2$ and $V \delta 3$ changed, but the usage of $V \gamma 9$ in TCR structure is still high. In both materials the percentage of the V 11 subpopulation was low. As we mentioned in Patients and Methods, the quantities of ${\mathrm{V} \delta 1^{+}}^{+}$were evaluated by the direct staining method. It is know $\mathrm{n}$ that there are discrepancies of relative cell percentages determined by direct and indirect staining procedures. We observed 2 cells $/ \mu \mathrm{l}(0.4 \%)$ in SLE patients and 11 cells $/ \mu \mathrm{l}(1.1 \%)$ in healthy donors with $\mathrm{V} \delta 1^{+}$phenotype. These results confirmed data which could be calculated from Table 3 (pan $\gamma \delta \mathrm{T}$ cells minus $\mathrm{V} \delta 2^{+}$and $\mathrm{V} \delta 3^{+}$subfractions; other unique Vo cells can be neglected). However, we have decided to present only the results (Tables 3 and 
Table 4. The frequency of $\gamma \delta$ T cell subtypes in peripheral blood of patients with SLE dependent on disease activity and immunosuppressive treatment (mean of cells number/ $\mu \mathrm{I} \pm \mathrm{SD}$ and range in parentheses)

\begin{tabular}{|c|c|c|c|c|c|c|}
\hline \multirow{2}{*}{$\begin{array}{l}\text { Cell } \\
\text { Subpopulation }\end{array}$} & \multicolumn{3}{|c|}{ SLE activity } & \multicolumn{3}{|c|}{ Immunosuppressive treatment } \\
\hline & $\begin{array}{c}\text { Active } \\
N=23\end{array}$ & $\begin{array}{c}\text { Inactive } \\
N=9\end{array}$ & $P$ value & $\begin{array}{c}\text { Treated } \\
N=22\end{array}$ & $\begin{array}{l}\text { Untreated } \\
\qquad N=10\end{array}$ & $P$ value \\
\hline $\operatorname{pan} \gamma \delta \mathrm{TCR}^{+}$ & $\begin{array}{l}41 \pm 38 \\
(4-125)\end{array}$ & $\begin{array}{c}47 \pm 49 \\
(14-146)\end{array}$ & NS & $\begin{array}{l}49 \pm 45 \\
(4-146)\end{array}$ & $\begin{array}{c}27 \pm 24 \\
(6-79)\end{array}$ & NS \\
\hline $\mathrm{V} \delta 2 \mathrm{TCR}^{+}$ & $\begin{array}{l}19 \pm 24 \\
(1-99)\end{array}$ & $\begin{array}{c}26 \pm 27 \\
(4-70)\end{array}$ & NS & $\begin{array}{l}24 \pm 28 \\
(1-99)\end{array}$ & $\begin{array}{c}13 \pm 11 \\
(4-33)\end{array}$ & NS \\
\hline $\mathrm{V} \delta 3 \mathrm{TCR}^{+}$ & $\begin{array}{l}22 \pm 29 \\
(0-108)\end{array}$ & $\begin{array}{c}28 \pm 29 \\
(5-90)\end{array}$ & NS & $\begin{array}{l}28 \pm 31 \\
(0-108)\end{array}$ & $\begin{array}{l}14 \pm 18 \\
(2-52)\end{array}$ & NS \\
\hline $\mathrm{V} \gamma 9 \mathrm{TCR}^{+}$ & $\begin{array}{l}21 \pm 26 \\
(1-107)\end{array}$ & $\begin{array}{c}29 \pm 27 \\
(4-82)\end{array}$ & NS & $\begin{array}{l}27 \pm 29 \\
(2-107)\end{array}$ & $\begin{array}{l}15 \pm 15 \\
(3-45)\end{array}$ & NS \\
\hline
\end{tabular}

4) obtained by the same, more objective technique. The $\mathrm{V} \delta^{+} 1^{+}$fraction, which usually increases as the response against tumor antigens, ${ }^{10,13}$ did not play the important role in our model.

No differences in $\gamma \delta$ T cells proportion as well as its V82, V83 and V $\gamma 9$ subpopulations were observed in patients with active and inactive disease (Table 4). However, the absolute numbers of $\gamma \delta \mathrm{T}$ cells and all three analysed subtypes of these cells were 2 times higher in patients treated with immunosuppressive drugs in comparison with untreated SLE patients. But they were also not significantly different (Table 4).

Furthermore the absolute number $\gamma \delta$ T cells in SLE specimens correlated positively with the total number of T CD3 ${ }^{+}$cells $(R=0.44 ; P=0.02)$, but not with the number of T CD4 ${ }^{+}$cells $(R=0.31 ; P>0.05)$ or NK cells $(R=0.037 ; P>0.05)$ (Fig. 2). It should be mentioned that double-colour cytometric tests of pan $\gamma \delta \mathrm{T}$ cells did not allow us to detect $\mathrm{CD}^{-}$and $\mathrm{CD}^{-}$positive $\gamma \delta$ $\mathrm{T}$ lymphocytes. This observation is considered in detail in the Discussion section.

\section{Discussion}

According to our data the absolute numbers of cells expressed $\gamma \delta$ TCR in most SLE blood specimens were significantly lower $(-40 \%, P<0.006)$ than in the control group. However, since the level of total T cell fraction (measured as $\mathrm{CD}^{+}$cells) was also decreased in the case of SLE, the mean values of the percentage $\gamma \delta \mathrm{T}$ cells of pan T lymphocytes were almost the same in both analysed populations $(7.1 \%$ vs. $6.3 \%$, respectively). Similar observations were made during the comparison of $\mathrm{V} \delta^{+}$and $\mathrm{V} \gamma 9^{+}$subtypes of pan $\gamma \delta \mathrm{T}$ cells.

The completely opposite result was obtained in the case $\mathrm{V} \delta 3^{+} \mathrm{T}$ cells. The very low amount of them was identified in peripheral blood of control donors (less $0.5 \%$ of pan T lymphocytes), but in specimens from SLE patients their increase was very significant and concerning both the absolute number of cells and the relative percentage value ( 20 vs. 2 cells, $P<0.001$ and $4.2 \%$ vs. $0.2 \%, P<0.0003$, in SLE and healthy donors, respectively). The diversity of the $\mathrm{V} \gamma$ region in TCR formation during disease development seems to be less important. The separate problem is the expression of co-repressors (CD4 and CD8) on studied cells. They are very important for normal $\alpha \beta \mathrm{T}$ cell function. We suspected that our observations in the case of CD4 antigen (lack of expression) were correct, but we did not exclude that CD8-negative staining was false, caused, in part, by instrument limitations. We suspect that pan $\gamma \delta \mathrm{T}$ cells in control blood specimens were CD8-negative; however, in peripheral blood of SLE patients at least some of pan $\gamma \delta \mathrm{T}$ cells weakly expressed CD8 antigen, as an activation effect of cells involved in autoimmune response (data not shown).

Our observation concerning V $83^{+}$cells' expansion in SLE patients is the first demonstration that this subset of $\gamma \delta$ T lymphocytes seems to be involved in SLE pathogenesis. Previously published data indicated the increase of pan $\gamma \delta$ T cells in peripheral blood from patients with this disease. ${ }^{30,31}$ Other works characte rised expanded subtypes as the polyclonal $V \delta 1^{+}$and $\mathrm{V} \delta 2^{+}$or $\mathrm{V} \gamma 2 / \mathrm{V} \delta 2^{+}$oligoclonal subsets. ${ }^{23}$ These discrepancies probably arose as the result of different features of analysed disease in particular groups of patients, and indicated that changes of several parameters are involved in the disease development

However, our results are to some extent unexpected, because most of the studies undertaken so far indicate that total levels of pan $\gamma \delta \mathrm{T}$ cells (calculated both as the cell number/ $\mu$ and as the relative percentage of pan $\mathrm{TCD} 3+$ lymphocyte fraction) were significantly higher in peripheral blood of patients with autoimmune diseases than in healthy donors. Janadi et al. ${ }^{32}$ observed the expansion $\mathrm{CD}^{+} \mathrm{CD} 29^{+}$ $\gamma \delta \mathrm{T}$ cells in the peripheral blood and synovial fluid of patients $w$ ith rheumatoid arthritis (RA). The elevation of pan $\gamma \delta$ T cells in the same materials of RA patients was stated by Keystone et al. ${ }^{3}$ It was also demon- 

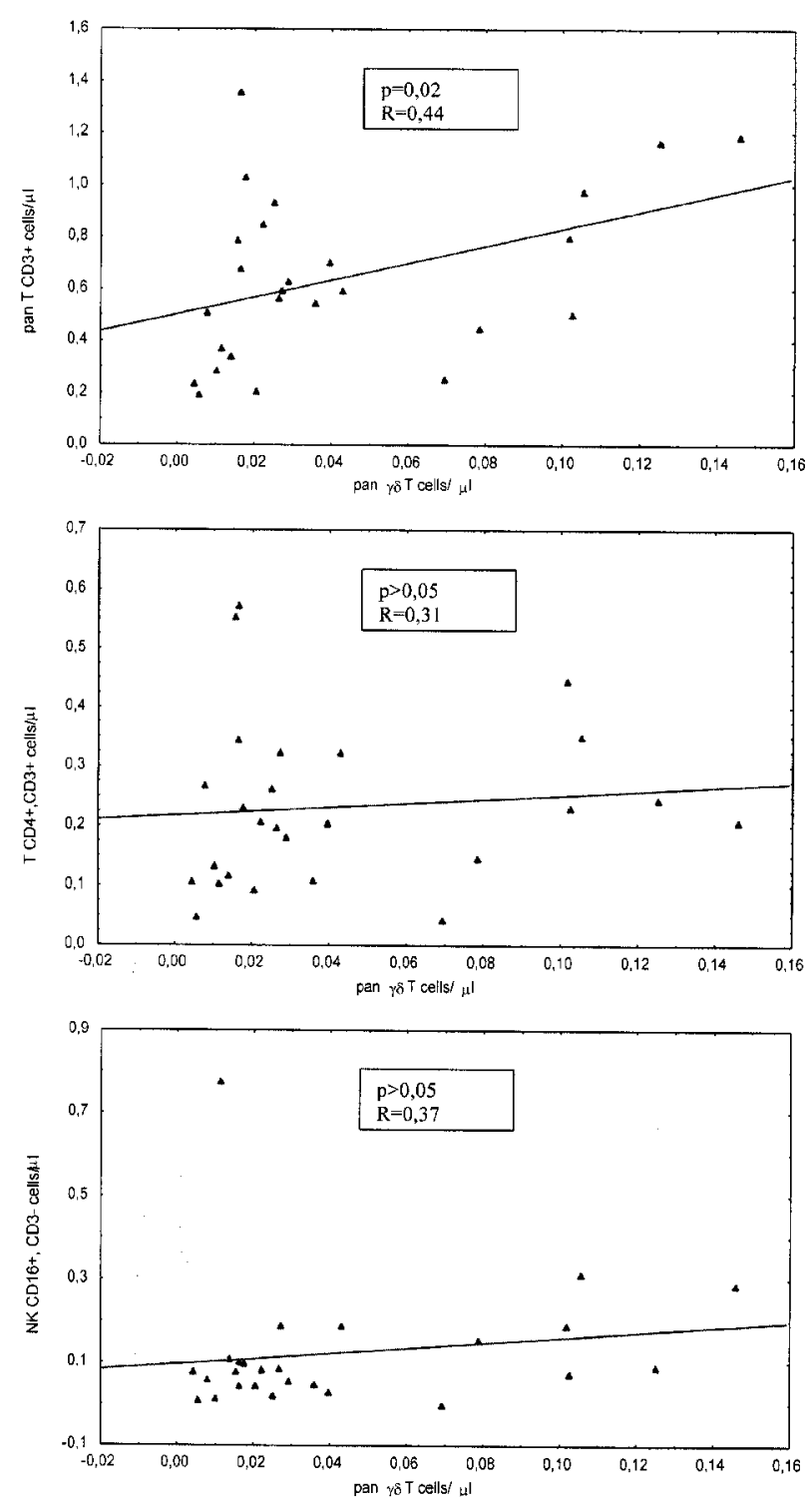

FIG. 2. Correlations between the number of pan $\gamma \delta^{+}$T cells and the number of $\mathrm{CD}^{+}, \mathrm{CD}^{+}$and NK cells in peripheral blood of SLE patients.

strated in many investigations that the involvement of $\gamma \delta \mathrm{T}$ lymphocytes in the pathogenesis of autoimmune diseases was most likely, because their expansion was always significant. It has been discussed in the studies concerning coeliac disease, ${ }^{34}$ multiple sclerosis, ${ }^{17,35}$ autoimmune thyroid diseases, ${ }^{36}$ autoimmune liver disease $^{37}$ and systemic sclerosis. ${ }^{20}$ However, in the cases of the above-specified diseases, the accumulation of $\gamma \delta \mathrm{T}$ cells occurred predominantly in pathologically changed tissues; their increases in peripheral blood of the same patients were less evident or even unnoticeable. We feel obliged to say that our study of peripheral blood cells was dictated by the pragmatic goal to find a simple, highly standardised test for some aspects of SLE diagnosis. Of course, we knew that the cell representation in blood was only the approximate image of the actual situation in affected tissues, but the reciprocal circulation of $\mathrm{T}$ lymphocytes in an organism could allow the description of real changes in $\gamma \delta \mathrm{T}$ cells, as it is observed in tumor infiltrating lymphocytes and peripheral circulation cell populations. ${ }^{10}$

In the case of our SLE patients investigation, the decrease of pan $\gamma \delta \mathrm{T}$ cells number (and similar events for $\mathrm{V} \delta 2^{+}$and $\mathrm{V} \delta 9^{+}$subtypes) partly resulted from general pan $\mathrm{T}$ lymphopenia, which was more intensive than in other SLE studies. Another reason for that phenomenon could be connected with the capacity of $\gamma \delta \mathrm{T}$ lymphocytes to very strong infiltration and pathological damage of target tissues, as skin and kidneys. Such accumulation, particularly V $\gamma 2 / \mathrm{V} \delta 2$ TCR expressed cells, was observed in disease-damaged skin of patients with chronic cutaneous lupus erythematosus ${ }^{23}$ and SLE. ${ }^{22}$ Probably in our case the ${\mathrm{V} \delta 3^{+}}^{+}$subfraction responded to autologous immune antigens. The persistent treatment of the most patients with glucocorticoids could be also responsible for the lower numbers of $\gamma \delta \mathrm{T}$ cells in peripheral blood from SLE individuals than in specimens from control donors. Several published data demonstrated that long-continued immunosuppressive therapy determined the disappearance of expanded $\gamma \delta \mathrm{T}$ cell subset, in both target tissues, and the peripheral blood of patients with polymyositis or other autoimmune diseases. ${ }^{30,38}$ Spinozzi et al. ${ }^{31}$ demonstrated data obtained from in vitro experiments that all $\mathrm{T}$ lymphocytes bearing the $\gamma \delta \mathrm{TCR}$ (isolated both from SLE patients and healthy individuals) were susceptible to dexamethasone, and steroid-induced apoptosis was basic mechanism responsible for cells death. They also demonstrated that 6 month glucocorticoids treatment normalised the increased SLE $\gamma \delta$ T cell subfraction in blood, simultaneously with clinical remission of the disease symptoms.

In our studies the analyses of immunosuppressive treatment influence on $\gamma \delta \mathrm{T}$ cell level were not such univocal. In all cell subtypes their amounts were two times higher in the treated patients than in untreated ones (but always lower than in specimens of control donors). It could be considered as a reconstruction process of the initial $\gamma \delta \mathrm{T}$ cells status, typical for normal blood. A relatively low number of studied cases can be responsible for statistical doubts. The reason why it was also observed for ${\mathrm{V} \delta 3^{+}}^{+} \mathrm{T}$ cells, which seem to compose the unique subtype in healthy individuals' blood, is unclear. A simple look at the data presented in Table 4 may lead to the conclusion that the frequencies of total $\gamma \delta \mathrm{T}$ cells and their particular subtypes in SLE patients were not generally determined by disease activity, evaluated according to the method of Liang et al. ${ }^{25}$ But statistically important, objective data could probably be obtained 
during the analysis of affected tissues. We registered the cell distribution in peripheral blood, which probably reflected only some functional tendencies occurring in tissues. The correlation between SLE activity and concentrations of some cytokines and their soluble receptors was detected in our previous investigations. ${ }^{26,27}$

Data from Table 2 and Figure 2 indicate, that although absolute amounts of pan $\mathrm{T} \mathrm{CD}^{+}$cells, $\mathrm{T}$ helper $\mathrm{CD}^{+}$cells and NK cells were significantly reduced in SLE patients, variations of $\mathrm{TCD}^{+}$and NK cells were not correlated with changes of pan $\gamma \delta \mathrm{T}$ cells. In such case the influence (if any) of compared cell populations on SLE development is independent.

At present there is little know $n$ about the function of $\gamma \delta \mathrm{T}$ cells in SLE pathogenesis. The recent experiments confirm that they really play a significant role in autoimmunity regulation in vivo, but some authors published contrary data, suggesting $\gamma \delta \mathrm{T}$ lymphocytes' responsibility for down-regulation of autoimmune diseases. ${ }^{5,36}$ The work of Peng et al. ${ }^{39}$ was the first demonstration in vivo that mice with $\gamma \delta$ $\mathrm{T}$ cells deficiency (TCR $\delta$-/MRL/lpr) developed a significantly more severe lupus-like disease and their mortality was twice that in normal MRL/lpr mice. However, $\gamma \delta \mathrm{T}$ lymphocytes caused also downregulation of the $\alpha \beta$ T cell response to infection and thus they could intensify the autoaggressive testis inflammation evoked by Listeria infection. ${ }^{40}$ Additionally it was show $\mathrm{n}$ that $\gamma \delta \mathrm{T}$ cells promoted the B cell mediated autoimmunity. ${ }^{41}$

All the above observations may indicate that different subtypes (or distinct clones) of $\gamma \delta \mathrm{T}$ lymphocytes realise separate, sometimes even opposite functions in induction of autoreactive immune responses, for example in SLE. It should be noted that their function is realised very early in ontogeny, and further disturbances of several metabolic pathways can change the final effects. We believe that the indicated observations do not reflect epiphenomenons, but univocal evidence of it has to be verified by additional experiments. We have initiated our future studies based on more cases, included cytometric analysis with cells isolated from affected tissues and proper controls. We have also extended our studies for molecular tests (RT-PCR detection of $\gamma \delta$ TCR discret, minor subpopulations, characterisation of their genomic structure and determination of clonality of expanded $\gamma \delta \mathrm{T}$ cells subtypes). Our study indicated that ${\mathrm{V} \delta 3^{+}}^{+}$subtype of $\gamma \delta \mathrm{T}$ cells seems to be involved in SLE pathogenesis; however, we accept the view that the autoimmunity does not develop from single abnormality, but rather from a number of different events.

ACKNOWLEDGEMENTS. We would like to thank Dr. Z Darzynkiewicz, Brander Cancer Research Institute, New York Medical College, for his methodical evaluation of our work.

\section{References}

1. Steinberg AD, Klinman DM. Pathogenesis of systemic lupus erythematosus. Rheum Dis Clin North Am 1988; 14:25-41

2. Swaak AJ, Nossent JC, Smeenk RJ. Systemic lupus erythematosus. Int J Clin Lab Res 1992; 22:190-5

3. Linker-Israeli M, Quismorio FP Jr, Howitz DA. CD8 ${ }^{+}$lymphocytes from patients with systemic lupus erythematosus sustain, rather than suppress, spontaneous polyclonal IgG production and synergize with $\mathrm{CD}^{+}$cells to support autoantibody synthesis. Arthritis Rheum 1990; 33:1216-25

4. Ishida H, Kumagai S, Umehara H, Sano H, Tagaya Y, Yodoi J, Imura $H$. Impaired expression of high affinity interleukin 2 receptor on activated lymphocytes from patients with systemic lupus erythematosus. J Immunol 1987; 139:1070-4

5. Sakane T, Steinberg AD, Green I. Studies of immune functions of patients with systemic lupus erythematosus: 1 . Dysfunction of suppressor T-cell activity related to impaired generation of, rather than response to, suppressor cells. Arthritis Rheum 1978; 21:657-64

6. Tsokos GC, Magrath JT, Balow JE. Epstein-Barr virus induces normal B cell responses but defective suppressor T cell responses in patients with systemic lupus erythematosus. J Im munol 1983; 131:1797-801

7. Bluestone JA, Khattri R, Sciammas R, Sperling AI. TCR $\gamma \delta$ cells: a specialized T-cell subset in the immune system. Annu Rev Cell Dev Biol 1995; 11:307-53

8. Brenner MB, McLean J, Dialynas DP, Strominger JL, Smith JA, Owen FL, Seidman JG, Rosen F, Krangel MS. Identification of a putative second T-cell receptor. Nature 1986; 322:145-9.

9. Lew AM, Pardoll DM, Maloy WL, Fow lkes BJ, Kruisbeek A, Cheng SF, et al. Characterization of T cell receptor gamma chain expression in a subset of murine thymocytes. Science 1986; 234:1401-5.

10. Davis MM and Bjorkman PJ. T-cell antigen receptor genes and T-cell recognition. Nature 1988; 334:395-402.

11. Bordessoule D, Gaulard P, Mason DY. Preferential localisation of human lymphocytes bearing gamma delta T-cell receptors to the red pulp of the spleen. J Clin Pathol 1990; 43:461-4

12. Jarry A, Cerf-Bensussan N, Brousse N, Selz F, Guy-Grand D. Subsets of $\mathrm{CD}^{+} \mathrm{T}$ cell receptor of $\alpha \beta$ or $\gamma 5$ and $\mathrm{CD}^{-}$lymphocytes isolated from normal human gut epithelium display phenotypical features different from their counterparts in peripheral blood. Eur J Immunol 1990; 20:1097-103.

13. De Libero G. Sentinel function of broadly reactive human $\gamma \delta \mathrm{T}$ cells. Im munol To day 1997; 18:22-6

14. Hayday A. Autoimmunity is antigen-specific suppression now unsuppressed? Curr Biol 1995; 5:47-50

15. Hayday A, Geng L. $\gamma \delta$ cells regulate autoimmunity. Curr Opin Immunol 1997; 9:884-9

16. Kaufmann $\mathrm{SH}$. Heat shock proteins and the immune response. Im munol To day 1990; 11:129-36

17. Stinissen P, Vandevyver G, Medaer R, Vandegaer L, Nies J, Tuyls L, Hafler $\mathrm{DA}$, Raus J, Zhang J. Increased frequency of $\gamma \delta \mathrm{T}$ cells in cerebrospinal fluid and peripheral blood of patients with multiple sclerosis. Reactivity cytotoxicity, and $\mathrm{T}$ cell receptor $\mathrm{V}$ gene rearrangements. I Im munol 1995; 154:4883-94

18. Holoshitz J, Koning F, Coligan JE, De-Bruyn J, Strober S. Isolation of CD4$\mathrm{CD}^{-}$mycobacteria reactive $\mathrm{T}$ lymphocyte clones from rheumatoid arthritis synovial fluid. Nature 1989; 339:226-9

19. Jacobs MR, Haynes BF. Increase in TCR $\gamma \delta$ T lymphocytes in synovia from rhe umatoid arthritis patients with active synovitis. J Clin Im m unol 1992; 12:130-8

20. Giacomelli R. Girculating $\mathrm{V}^{+} 1$ cells are activated and accumulate in the skin of systemic sclerosis patients. Arthritis Rheum 1998; 41:327-34

21. Yurovsky VV, Sutton PA, Schulze DH,Wigley FM, Nise RA, Howard RF, White B. Expansion of selected $V \delta 1^{+} \gamma \delta \mathrm{T}$ cells in systemic sclerosis patients. J Im munol 1994; 153: 881-91

22. Olive C, Gatenby PA, Serjeantson SW. Restricted junctional diversity of T cell receptor delta gene rearrangements expressed in systemic lupus erythematosus (SLE) patients. Clin Exp Im munol 1994; 97:430-8

23. Volc-Platzer B, Anegg B, Milota S, Pickl W, Fisher G. Accumulation of $\gamma \delta$ $\mathrm{T}$ cells in chronic cutaneous lupus erythematosus. J Invest Dermatol 1993; 100:84S-91S

24. Tan EM, Cohen AS, Fries JF, Masi AT, McShane DJ, Rothfield NF, et al. The 1982 revised criteria for the classification of systemic lupus erythematosus. Artritis Rheum 1982; 25:1271-7

25. Liang MH, Socher SA, Larson MG, Schur PH. Reliability and validity of six systems for the clinical assessment of disease activity in systemic lupus erythematosus. Arthritis Rheum 1989; 32:1107-18

26. Robak E, Sysa-Jedrzejowska A, Robak T, Stepien H, Wozniacka A, Waszozykowska E. Tumor necrosis factor $\alpha$ (TNF- $\alpha$ ), interleukin-6 (IL-6) and their soluble receptors (sTN- $\alpha$-Rp 55 and sIL-6R) serum levels in systemic lupus erythematodes. Mediators Inflamm 1996; 5:435-41

27. Robak E, Sysa-Jedrzejowska A, Stepień H, Robak T. Circulating interleukin-6 type cytokines in patients with systemic lupus erythematosus. Eur Cytokine Netw 1997; 8:281-6

28. Linker-Israei M, Deans RJ, Wallace DJ, Prehn J, Ozeri-Chen T, Klinenberg JR. Elevated levels of endogenous IL-6 in systemic lupus erythematosus. A putative role in pathogenesis. JImmunol 1991; 147:117-23 
29. Bartkowiak J, Bloński JZ, Niewiadomska H, Kulczycka D, Robak T. Characterization of $\gamma \delta \mathrm{T}$ cells in peripheral blood from patients with B-cell chronic lymphocytic leukaemia. Biomed Letters 1998; 58:19-30

30. Ge rli R, Agea E, Bertotto A, Tognellini R, Flenghi L, Spinozzi F, Velardi A, Grignani F. Analysis of T cells bearing different isotypic forms of the $\gamma \delta \mathrm{T}$ cell receptor in patients with systemic autoimmune diseases. J Rheumatol $1991 ; 18: 1504-10$

31. Spinozzi F, Agea F, Bistoni O, Travetti A, Migliorati G, Moraca R, et al. T lymphocytes bearing $\gamma \delta \mathrm{T}$ cell receptor are susceptible to steroid induced programmed cell death. Scand J Im munol 1995; 41:504-8

32. al -Janadi M, al-Balla S, al.-Dalaan A, Raziuddin S. Cytokine production by helper $T$ cell populations from the synovial fluid and blood in patients with rheumatoid arthritis. J Rheumatol 1993; 20:1647-53

33. Keystone E, Rittershaus C, Wood N, Snow KM, Flatow J, Purvis JC. Elevation of $\gamma \delta$ T cell subset in peripheral blood and synovial fluid of patients with rheumatoid arthritis. Clin Exp Immunol 1991; 84:78-82

34. Halstensen TS, Scott H, Brandtzaeg P. Intraepithelial T cells of TCR $\gamma \delta^{+}$ $\mathrm{CD} 8^{-}$and $\mathrm{V} \delta 1 / \mathrm{J} \delta 1^{+}$phenotypes are increased in coeliac disease. Scand J Immunol 1989; 30:665-72

35. Selmaj K, Brosnan CF, Raine CS. Colocalization of lymphocytes bearing $\gamma \delta \mathrm{T}$ cell receptor and heat shock protein hsp $65^{+}$oligodendrocytes in multiple sclerosis. Proc Natl Acad Sci USA 1991; 88:6452-6
36. Roura-Mir IC. $\gamma \delta$ Lymphocytes in endocrine autoimmunity: evidence of expansion in Graves' disease but not in type I diabetes. Clin Exp Imm unol 1993; 92:288-95

37. Martins SE, Graham AK, Chapman RW, Fleming KA. Elevation of $\gamma \delta \mathrm{T}$ lymphocytes in peripheral blood and livers of patients with primary sclerosing cholangitis and other autoimmune liver diseases. Hepatology 1996; 23:988-93

38. Hohlfeld R, Engel AG, Ii K, Harper MC. Polymyositis mediated by T lymphocytes that express the $\gamma \delta$ receptor. N Engl J Med 1991; 324:877-81

39. Peng SL, Madaio MP, Hayday A, Craft J. Propagation and regulation of systemic autoimmunity by $\gamma \delta$ T cells. J Imm unol 1996; 157:5689-98

40. Mukasa A, Hiromatsu K, Matsuzaki G, O’Brien R, Born W, Namoto K. Bacterial infection of the testis leading to autoggressive immunity triggers apparently opposed responses of alpha be ta and gamma delta $\mathrm{T}$ cells. J Im munol 1995; 155:2047-56

41. Peng SL, Madaio MP, Hughes DP, Crispe IN, Owen MJ, Wen L, Hayday A, Craft J. Murine lupus in the absence of $\gamma \delta$ T cells. J Im munol 1996; 156:4041-9

\section{Accepted 24 January 2000}




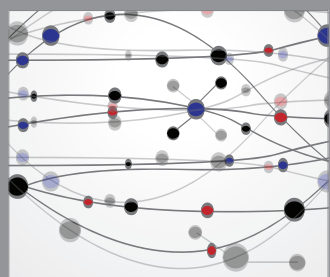

The Scientific World Journal
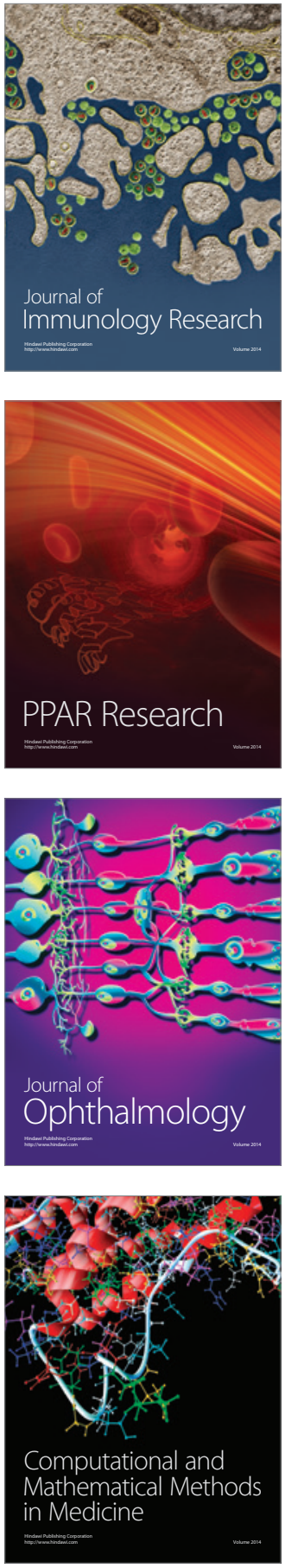

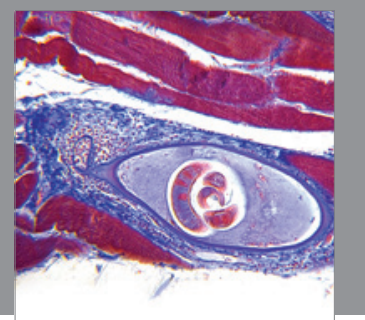

Gastroenterology

Research and Practice
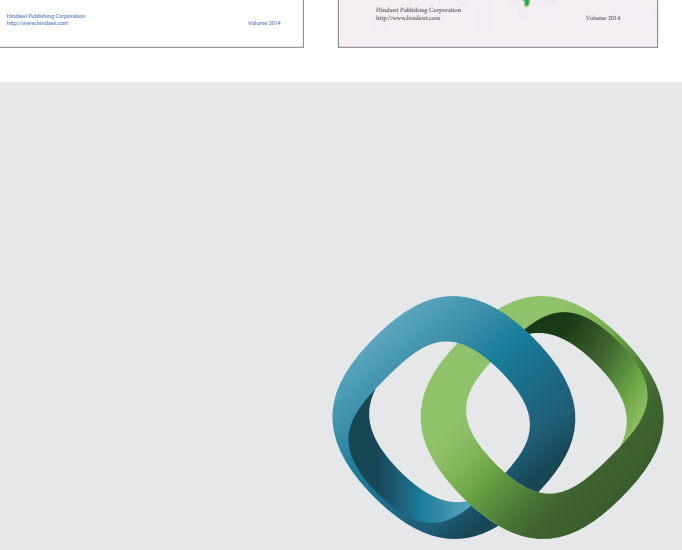

\section{Hindawi}

Submit your manuscripts at

http://www.hindawi.com
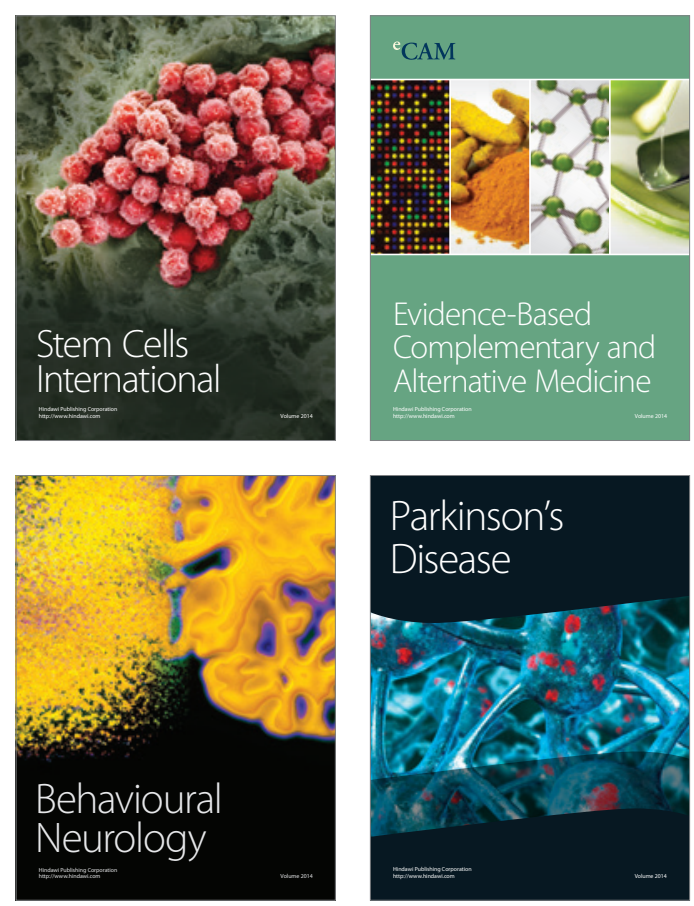

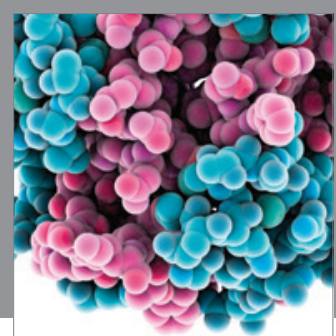

Journal of
Diabetes Research

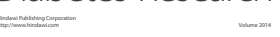

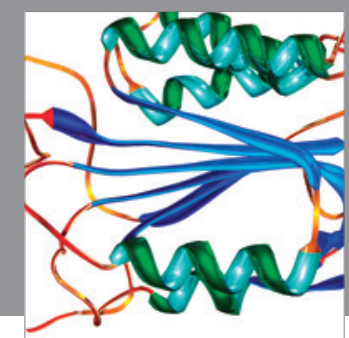

Disease Markers
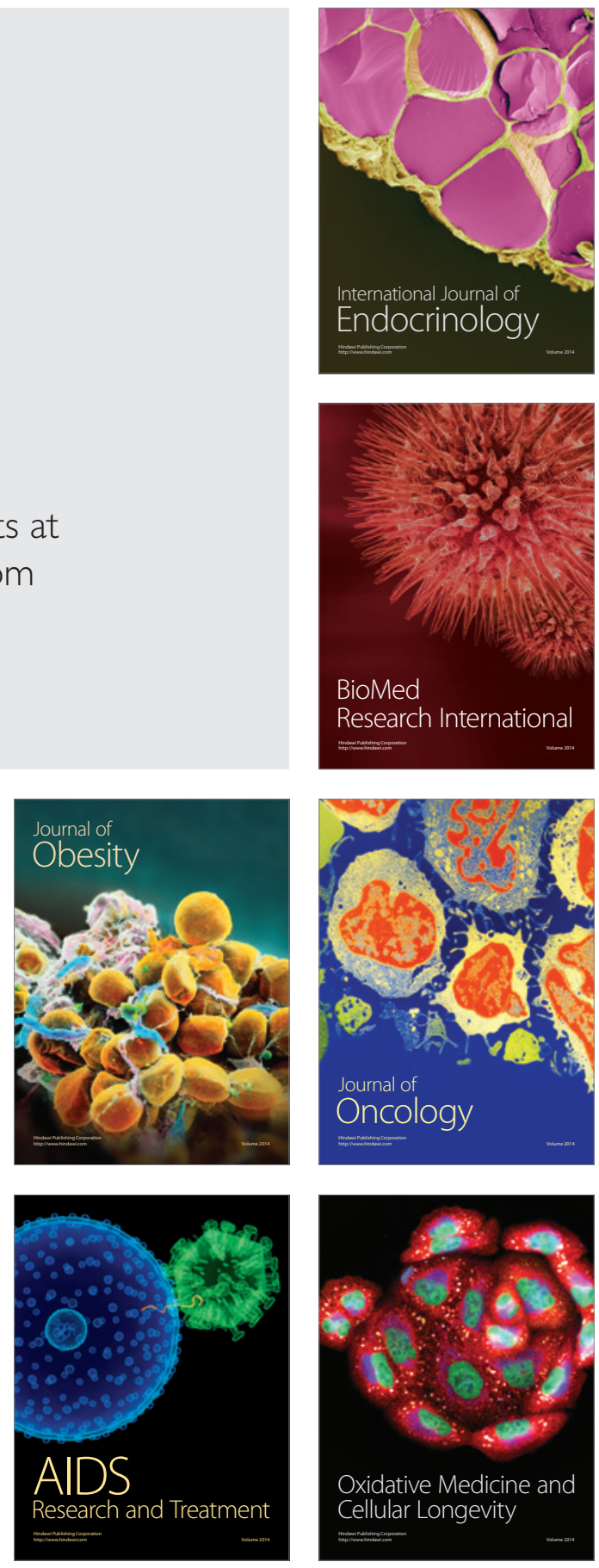